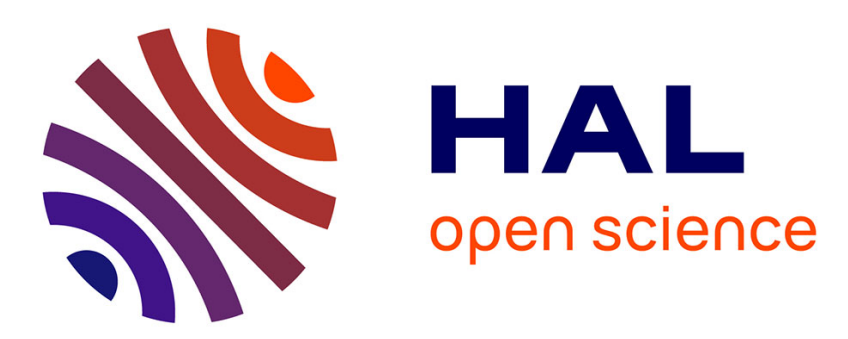

\title{
Temporal aspects of macroscopic changes in rainbow trout (Salmo gairdneri) oocytes before ovulation and of ova fertility during the post-ovulation period; effect of treatment with $17 \alpha$-hydroxy-20 $\beta$-dihydroprogesterone
} C. Bry

\section{- To cite this version:}

C. Bry. Temporal aspects of macroscopic changes in rainbow trout (Salmo gairdneri) oocytes before ovulation and of ova fertility during the post-ovulation period; effect of treatment with $17 \alpha$-hydroxy20 $\beta$-dihydroprogesterone. Aquaculture, 1981, 24, pp.153-160. 10.1016/0044-8486(81)90052-1 . hal01600680

\section{HAL Id: hal-01600680 \\ https://hal.science/hal-01600680}

Submitted on 2 Jun 2020

HAL is a multi-disciplinary open access archive for the deposit and dissemination of scientific research documents, whether they are published or not. The documents may come from teaching and research institutions in France or abroad, or from public or private research centers.
L'archive ouverte pluridisciplinaire HAL, est destinée au dépôt et à la diffusion de documents scientifiques de niveau recherche, publiés ou non, émanant des établissements d'enseignement et de recherche français ou étrangers, des laboratoires publics ou privés.

\section{다(1)(2)}

Distributed under a Creative Commons Attribution - ShareAlikel 4.0 International 


\section{TEMPORAL ASPECTS OF MACROSCOPIC CHANGES IN RAINBOW TROUT (SALMO GAIRDNERI) OOCYTES BEFORE OVULATION AND OF OVA FERTILITY DURING THE POST-OVULATION PERIOD; EFFECT OF TREATMENT WITH $17 \alpha$-HYDROXY-20 $\beta$-DIHYDROPROGESTERONE}

\section{BRY}

Laboratoire de Physiologie des Poissons, I.N.R.A., 78350 Jouy-en-Josas (France)

(Accepted 25 August 1980)

\section{ABSTRACT}

Bry, C., 1981. Temporal aspects of macroscopic changes in rainbow trout (Salmo gairdneri) oocytes before ovulation and of ova fertility during the post-ovulation period; effect of treatment with $17 \alpha$-hydroxy-20 $\beta$-dihydroprogesterone. Aquaculture, $24: 153-160$.

Ovulation induced by a single injection of $17 \alpha$-hydroxy-20 $\beta$-dihydroprogesterone $(17 \alpha-20 \beta \mathrm{P})$ in rainbow trout at the subperipheral germinal vesicle stage was compared with spontaneous ovulation. Three criteria were considered: the time course of the maturation-ovulation sequence, the embryo and fry viability, and the rate of aging of ova retained in the body cavity after ovulation.

Following treatment with $17 \alpha-20 \beta \mathrm{P}$ at $13^{\circ} \mathrm{C}$, the various stages of oocyte maturation took place between day 1 and day 4 and ovulation occurred on days 3,4 , and 5 with a peak on day 4 . The same timing was observed in the case of spontaneous ovulation.

Treatment with $17 \alpha-20 \beta$ P did not affect embryo or fry viability until the end of yolk sac resorption.

Lastly, in both natural and steroid-induced ovulation, ova fertility had decreased significantly by the 9 th day of retention in the female body cavity, at $13^{\circ} \mathrm{C}$. The overall rate of ova aging was similar in both groups. These data demonstrate that ovulation induced by $17 \alpha-20 \beta \mathrm{P}$ at the subperipheral germinal vesicle stage is close to the natural, spontaneous, process.

\section{INTRODUCTION}

At the end of vitellogenesis, trout oocytes undergo a series of changes which result in oocyte maturation (resumption of meiosis) and ovulation (expulsion of the mature oocyte from the follicle). Some of these modifications are macroscopic, may be easily observed and have been used to define a number of stages between the end of vitellogenesis and the achievement of ovulation (Jalabert et al., 1976).

Regarding the endocrine control of the maturation process, $17 \alpha$-hydroxy$20 \beta$-dihydroprogesterone (4 pregnene-17 $\alpha, 20 \beta$ diol-3 one, abbreviation: $17 \alpha-20 \beta \mathrm{P}$ ), a natural steroid occurring at high concentrations in female 
salmon plasma at the time of spawning (Idler et al., 1960), appears to be the most likely mediator of oocyte maturation in trout, and is also able to induce follicle preparation for ovulation (in vitro experiments: Fostier et al., 1973; Jalabert, 1976, 1978). In vivo, $17 \alpha-20 \beta \mathrm{P}$ can induce the full sequence of oocyte maturation and ovulation when injected into females having oocytes with the germinal vesicle (GV) in the subperipheral position (Jalabert et al., 1976).

Spawning behaviour does not usually take place in captive female rainbow trout and the ova remain in the body cavity after ovulation. After a few days or a few weeks, depending on the water temperature and on the donor female (Sakai et al., 1975; Escaffre et al., 1977), ova fertility gradually decreases, whereas these 'over-ripened' ova undergo some morphological changes (Nomura et al., 1974).

The aim of the present study was to define some temporal aspects of the

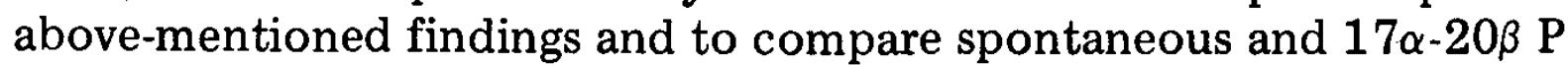
ovulations from various standpoints. Specifically, we intended to answer the following questions:

(i) what is the in vivo duration of each oocyte stage between the "submature" stage (GV in subperipheral position) and ovulation, in the case of both spontaneous and steroid-induced ovulation?

(ii) does treatment with $17 \alpha-20 \beta \mathrm{P}$ affect fry viability until the end of yolk sac resorption?

(iii) does treatment with $17 \alpha-20 \beta \mathrm{P}$ exert some influence on the rate of aging of the ova in the female body cavity?

\section{MATERIAL AND METHODS}

The experiments were carried out during the spawning season in December and January, using 3-year-old rainbow trout (Salmo gairdneri) weighing $500-800 \mathrm{~g}$. The animals were kept in spring water of constant temperature $\left(12.7-13.0^{\circ} \mathrm{C}\right)$ and under natural photoperiod.

Twice a week, each female was anesthetized in an aqueous solution $(0.5 \% 0)$ of 2-phenoxyethanol (Merck) and a few oocytes were squeezed out by abdominal stripping. On five occasions in a 1-month period, six to eight fish which had oocytes with a GV in subperipheral position were selected: at this stage the GV appears as a whitish spot with indistinct outlines, in the cytoplasmic area (Jalabert et al., 1976). On the day that the stage of the subperipheral GV was first detected, the fish concerned were separated into two equal groups. One lot received a'single intraperitoneal injection of $17 \alpha-20 \beta \mathrm{P}$ $(2 \mathrm{mg} / \mathrm{kg}$ ). A crude preparation of $17 \alpha-20 \beta \mathrm{P}$ (see Jalabert et al., 1977) was used. Prior to injection, $17 \alpha-20 \beta \mathrm{P}$ was first dissolved in pure ethanol, then precipitated as a suspension in physiological saline $(\mathrm{NaCl} 8 \%)$ at the time of injection (ethanol/saline $=20 / 80$ ). The control group was injected solely with the same ethanol/saline vehicle. The same volume of vehicle $(1 \mathrm{ml} / \mathrm{kg})$ was used in all animals. 
The steroid-treated lot and the control group comprised 19 and 17 fish respectively.

After injection, each female was submitted to anesthesia and ovarian sampling at 24-h intervals until day 20 or until ovulation (whichever occurred first). In order to minimize handling, the anesthetic solution was placed adjacent to the holding raceway. Furthermore, the handling-anesthesia-sampling procedure did not exceed $5 \mathrm{~min}$ for each fish. The stage of oocyte development was determined under a binocular microscope according to the following classification (Jalabert et al., 1976):

0: GV in subperipheral position (GV with indistinct outlines, oocyte opaque);

1: GV in peripheral position (GV with sharp outlines, oocyte opaque);

2: Maturing oocyte before GV breakdown (GV still visible, clearing of the yolk, peripheral oil droplets);

3: Maturing oocyte after GV breakdown:

4: Matured and ovulated oocyte.

On the day of ovulation and at 3-day intervals thereafter until day 12, artificial insemination was performed on about 200 ova with sperm pooled from five males according to the dilution technique (dilution rate: $1 / 100$ ) described by Billard (1977). Particular care was taken when collecting the ova, in order to minimize possible mechanical damage to the sampled ova as well as to those remaining in the body cavity.

Eggs were incubated on fine mesh troughs at constant temperature (12.7$13.0^{\circ} \mathrm{C}$ ), and dead eggs were removed every 2 days. Embryo survival was checked at the advanced eyed stage, shortly before hatching (260 degreedays). Hatching success (number of live hatched larvae at 330 degree-days/ number of eyed eggs at 260 degree-days, \%) was monitored in all the batches inseminated on the day of ovulation or on day 9 post-ovulation. Resorption success (number of live swimming fry at 500 degree-days/number of live hatched larvae at 330 degree-days, \%) was recorded in part of the lots inseminated on the day of ovulation.

\section{Statistical analysis}

Statistical differences between means were calculated using analysis of variance, or paired $t$-test whenever applicable, on data expressed through $\operatorname{arc} \sin \sqrt{\text { proportion }}$ transformation.

\section{RESULTS}

\section{Duration of oocyte stages}

Following treatment with $17 \alpha-20 \beta$ P, 15 females (79\%) ovulated between day 3 and day 5 . One female ovulated on day 7 and in the remaining three 
animals apparently complete oocyte maturation (stage 3 ) took place but was not followed by ovulation. The timing of the maturation-ovulation sequence (stages $2,3,4$ ) is shown in Fig. 1 for the 15 synchronized fish: stage 2 (beginning of oocyte maturation) was observed on day 1 , stage 3 on days 2 and 3 and ovulations peaked on day 4 .

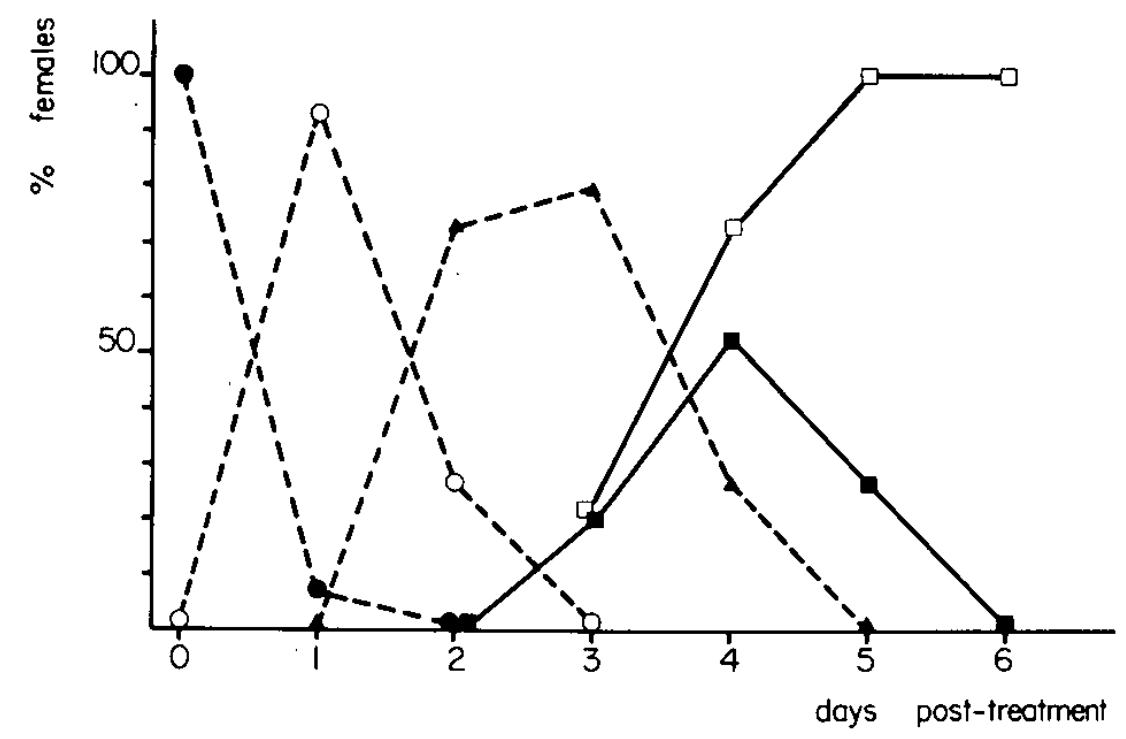

Fig. 1. Temporal characteristics of oocyte maturation and ovulation induced in rainbow

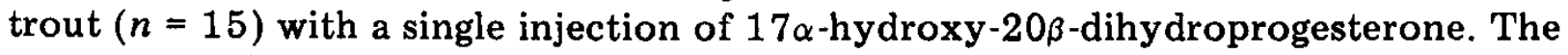
percentage of females at a given stage is shown as a function of time post-treatment. Water temperature is $13^{\circ} \mathrm{C}$. Oocytes stages: $\ldots \ldots \ldots \ldots$ Stage $0 ; 0 \ldots \ldots \ldots$........ Stage 2; $\triangle . . . . . . .$. Stage 3; — Stage 4; $\square$ Stage 4 (cumulative percentages).

The time interval between the first detection of the GV in the subperipheral position and the beginning of spontaneous maturation (stage 2) was monitored in the control lot and showed high variability (range: 2-14 days). In contrast, once maturation began (stage 2), the full maturation-ovulation sequence developed and with the same time pattern as in the steroid-treated group: ovulation occurred $2-3$ days after stage 2 .

\section{Effect of treatment with $17 \alpha-20 \beta$ P on embryo and fry viability}

As shown in Table I, both the control lot (spontaneous ovulation) and the $17 \alpha-20 \beta$ P-treated lot exhibited high rates (over $90 \%$ ) of success with respect to embryonic development, hatching and yolk sac resorption. Although the control lot yielded slightly better results, this trend was not significant within the period of development considered here $(P>0.05)$.

Effect of treatment with $17 \alpha-20 \beta P$ on the development of ova fertility following in vivo retention (Fig. 2)

In both the control and $17 \alpha-20 \beta$ P-treated groups, egg quality, assessed by the percentage of eyed eggs at 260 degree-days, remained at its high initial 


\section{TABLE I}

Percentage of eyed eggs, and success of hatching and yolk sac resorption following spontaneous ovulation (control lot) or $17 \alpha-20 \beta$ P induced ovulation

\begin{tabular}{llll}
\hline & $\begin{array}{l}\text { Eyed eggs } \\
(\%)\end{array}$ & $\begin{array}{l}\text { Hatching success } \\
(\%)\end{array}$ & $\begin{array}{l}\text { Resorption success } \\
(\%)\end{array}$ \\
\hline Control lot & $\begin{array}{c}91.3(n=17) \\
{[83-99]}\end{array}$ & $\begin{array}{c}97.8(n=17) \\
{[89-100]}\end{array}$ & $\begin{array}{c}97.9(n=5) \\
{[93-100]}\end{array}$ \\
$\begin{array}{l}17 \alpha-20 \beta \mathrm{P} \\
\text { treated lot }\end{array}$ & $\begin{array}{c}89.1(n=15) \\
{[78-97]}\end{array}$ & $\begin{array}{c}96.0(n=15) \\
{[87-100]}\end{array}$ & $\begin{array}{c}94.8(n=5) \\
{[90-98]}\end{array}$ \\
\hline
\end{tabular}

$n=$ number of determinations.

The range is indicated between square brackets.

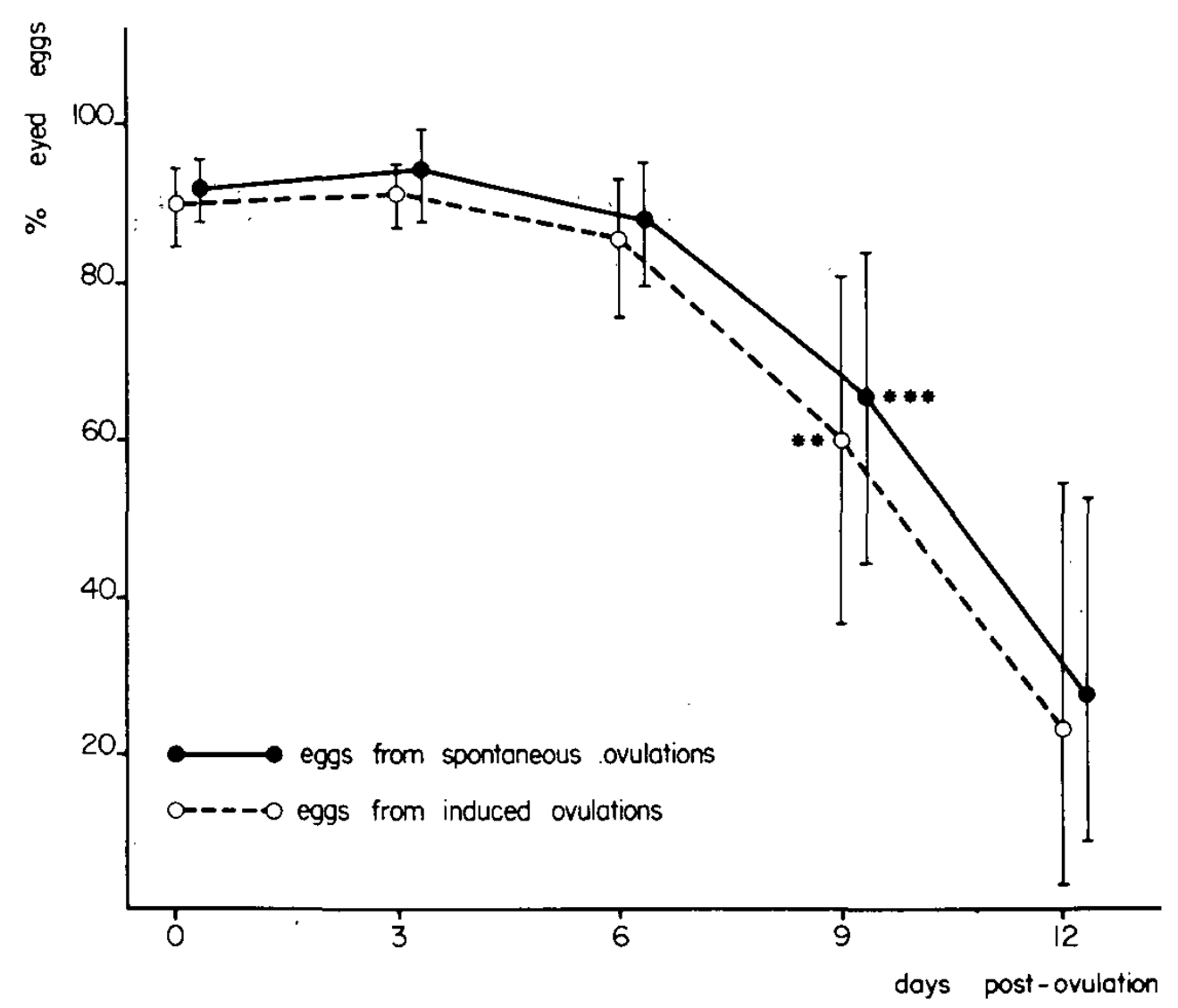

Fig. 2. Effect of the in vivo retention of ova on percentages of eyed eggs, after spontaneous or induced ovulation. In each lot, statistical significance of difference with mean initial percentage is indicated as follows: $* * *$ Very highly significant $(P<0.001)$; ** Highly significant $(P<0.01)$. Vertical bars show confidence limits at the $95 \%$ level of probability.

level (close to $90 \%$ ) until day 3 after ovulation. On day 6, a 4-5\% (absolute values) drop from the initial level occurred; this trend, however, was not statistically significant $(P>0.05)$. In both lots, the mean percentages of eyed eggs decreased sharply between day 6 and day 9 . The differences in fertility between day 0 and day 9 were highly significant (control lot: $P<0.001$; induced lot: 
$P<0.01$ ) and amounted to $30 \%$. This pattern continued after day 9: twelve days after ovulation, the percentages of eyed eggs dropped to 27.6 (control lot) and 23.1 (induced lot).

There was a large animal-to-animal variation in the time course of the fertility decrease: some females exhibited a significant loss on day 6 , while others still retained their initial gamete quality on day 9 . This phenomenon is well illustrated by the large increase in the coefficient of variation relative to the percentage of eyed eggs, observed during the post-ovulation period: less than $10 \%$ (days $0-3$ ), 14-19\% (day 6), 45-120\% (days 9-12).

The control group and the $17 \alpha-20 \beta \mathrm{P}$ treated lot were compared for fertility between day 0 and day 12 after ovulation. Although mean egg quality was always slightly inferior in the induced lot, this difference was not significant at the $5 \%$ level of probability.

Lastly, the comparison of initial and day 9 hatching success indicated that the aging phenomenon of the ova did also affect the efficiency of hatching $(P<0.01)$ : between day 0 and day 9 , hatching success decreased by $15 \%$ (absolute value) in the control lot and by $13 \%$ in the treated lot.

\section{DISCUSSION}

On the basis of the three criteria considered in this work (time course of maturation-ovulation, embryo viability, rate of ova aging), ovulation induced by a single injection of $17 \alpha-20 \beta \mathrm{P}$ in rainbow trout having oocytes with subperipheral germinal vesicle appears to be extremely similar to the natural, spontaneous process. At this stage of oocyte development, treatment with $17 \alpha-20 \beta \mathrm{P}$ triggers the full maturation-ovulation sequence at $13^{\circ} \mathrm{C}$, thus synchronizing ovulations between day 3 and day 5 after injection. At $13^{\circ} \mathrm{C}$ ovulations spread over a 3-day period. This fact, and our data on the rate of ova aging at that temperature, indicate clearly the possibility of collecting the ova and performing artificial insemination on day 5 or 6 post-treatment. The most precocious ova would then be only 3 days old and their quality could not be affected.

Mean egg quality was slightly inferior in the induced lot. It is not possible to determine whether the non-significant differences in quality result from an initial difference (prior to treatment) between the two groups, or from treatment with $17 \alpha-20 \beta$ P. In the latter case, the slightly depressed performance of the steroid-treated females might be related to the lower gonadotropin levels observed during the post-ovulation period in females treated with $17 \alpha-20 \beta$ P (Jalabert et al., 1980).

It should be emphasized that the stage of the subperipheral GV is close to the onset of natural maturation since only 2-14 days separated those events in our study. Similarly, the time-lag between the subperipheral GV stage and ovulation ranged from less than 5 days to about 30 days, in a previous work (Jalabert et al., 1976). Such individual variations may be explained by the possibility that handling and/or anesthesia might advance maturation in some 
submature females (Jalabert et al., 1978). Another reason lies in the fact that the position of the GV is only a gross indicator of ovarian responsiveness with regard to ovulation. As indicated by the percentage of non-ovulating females in this study (16\%) and in a previous work (13\%, Jalabert et al., 1976) a group of females selected at the subperipheral GV stage remains heterogeneous to some extent. Heterogeneity was also found at a more precocious stage (3-8 weeks before natural ovulation) by Jalabert et al. (1978): while most of the fish matured (after $17 \alpha-20 \beta$ P treatment), $75 \%$ did not ovulate. The remaining $25 \%$ matured and ovulated, responding like females having oocytes with subperipheral GV. The above discussion points out the need for more reliable criteria of ovarian development and responsiveness.

Peak ovulation occurred on day 4 (i.e. approximately 50 degree-days) after $17 \alpha-20 \beta \mathrm{P}$ treatment in the present experiment. The same degree-days interval between treatment and ovulation was found in female pike (Esox lucius) injected with salmon gonadotropin at $12^{\circ} \mathrm{C}$ (De Montalembert et al., 1978) as well as at 8 and $15^{\circ} \mathrm{C}$ (Billard, personal communication, 1980). In our in vivo study, oocyte maturation (stage 3) was mostly observed on day 2 or 3 (25-40 degree-days). This result is comparable to the timing of in vitro maturation (40 degree-days, Jalabert, 1978).

Our data on the quality of ova retained in the body cavity after ovulation show a highly significant decrease by day 9 and an even more important decline between day 9 and day 12 , at $13^{\circ} \mathrm{C}$. Two previous works (Sakai et al., 1975; Escaffre et al., 1977) indicated a slower rate of ova aging in rainbow trout. This discrepancy most probably results from the lower water temperatures in the latter studies and from the size and origin of the experimental females, as emphasized by Escaffre et al. (1977). Lastly, our findings demonstrate that the aging phenomenon affects not only fertilizability and/or early embryonic development, but also hatching, though to a lesser extent. In addition, ova aging may have belated effects during the post-hatching period, as shown by the increased proportion of abnormal alevins (Sakai et al., 1975).

\section{REFERENCES}

Billard, R., 197.7. Utilisation d'un système Tris-glycocolle pour tampónner le dilueur d'insémination pour truite. Bull. Fr. Piscic., 264: 102-112.

De Montalembert, G., Jalabert, B. and Bry, C., 1978. Precocious induction of maturation and ovulation in northern pike (Esox lucius). Ann. Biol. Anim. Biochim. Biophys., 18: 969-975.

Escaffre, A.M., Petit, J. and Billard, R., 1977. Evolution de la quantité d'ovules récoltés. et conservation de leur aptitude à être fécondés au cours de la période post-ovulatoire chez la truite arc-en-ciel. Bull. Fr. Piscic., 265: 134-142.

Fostier, A., Jalabert, B. and Terqui, M., 1973. Action prédominante d'un dérivé hydroxylé de la progestérone sur la maturation in vitro des ovocytes de la truite arc-en-ciel Salmo gairdneri. C.R. Acad. Sci., Paris, 277: 421-424.

Idler, D.R., Fagerlund, U.H.M. and Ronald, A.P., 1960. Isolation of pregn-4-ene-17 $\alpha, 20 \beta$ diol-3-one from the plasma of Pacific Salmon. Biochem. Biophys. Res. Comm., 2:133137. 
Jalabert, B., 1976. In vitro oocy te maturation and ovulation in rainbow trout (Salmo gairdneri), northern pike (Esox lucius), and goldfish (Carassius auratus). J. Fish.: Res. Board Can., 33: 974-988.

Jalabert, B., 1978. Production of fertilizable oocytes from follicles of rainbow trout (Salmo gairdneri) following in vitro maturation and ovulation. Ann. Biol. Anim. Biochim. Biophys., 18: 461-470.

Jalabert, B., Bry, C., Breton, B. and Campbell, C., 1976. Action de la $17 \alpha$-hydroxy-20 dihydroprogestérone et de la progestérone sur la maturation et l'ovulation in vivo et sur le niveau d'hormone gonadotrope plasmatique t-GTH chez la truite arc-en-ciel Salmo gairdneri C.R. Acad. Sci., Paris, 281: 811-814.

Jalabert, B., Breton, B., Brzuska, E., Fostier, A. and Wieniawski, J., 1977. A new tool for induced spawning: the use of $17 \alpha$-hydroxy-20 $\beta$-dihydroprogesterone to spawn carp at low temperature. Aquaculture, 10: 353-364.

Jalabert, B., Breton, B. and Fostier, A., 1978. Precocious induction of oocyte maturation and ovulation in rainbow trout (Salmo gairdneri): problems when using $17 \alpha$-hydroxy20 $\beta$-dihydroprogesterone. Ann. Biol. Anim. Biochim. Biophys., 18: 977-984.

Jalabert, B., Breton, B. and Bry, C., 1980. Evolution de la gonadotropine plasmatique t-GTH après synchronisation des ovulations par injection de $17 \alpha$-hydroxy-20 $\beta$-dihydroprogestérone chez la Truite arc-en-ciel Salmo gairdneri. C.R. Acad. Sci., Paris, 290: 1431-1434.

Nomura, M., Sakai, K. and Takashima, F., 1974. The over-ripening phenomenon of rainbow trout. I - Temporal morphological changes of eggs retained in the body cavity after ovulation. Bull. Jap. Soc. Sci. Fish., 40: 977-984.

Sakai, K., Nomura, M., Takashima, F. and Oto, H., 1975. The over-ripening phenomenon of rainbow trout. II - Changes in the percentage of eyed eggs, hatching rate and incidence of abnormal alevins during the process of over-ripening. Bull. Jap. Soc. Sci. Fish., 41: 855-860. 